\title{
EPITHELIOCYSTIS DISEASE IN CULTURED PACU (PIARACTUS MESOPOTAMICUS) IN BRAZIL
}

\author{
J. SZAKOLCZAi ${ }^{1 *}$, F. VETÉSI $^{1}$ and S. R. PITZ ${ }^{2}$ \\ ${ }^{1}$ Department of Pathology and Forensic Veterinary Medicine, University of Veterinary \\ Science, H-1400 Budapest, P.O. Box 2, Hungary; ${ }^{2}$ University of Blumenau, Blumenau \\ $\mathrm{SC}$, Brazil
}

(Received January 4, 1999; accepted March 10, 1999)

\begin{abstract}
Epitheliocystis disease was diagnosed in a cultured pacu (Piaractus mesopotamicus Holmberg, 1893) stock on the basis of gross pathological (greyishwhite, pinpoint- or pinhead-sized focal areas, connected strongly to the gill lamellae) and histopathological examinations (hypertrophic cells $10-40 \mu \mathrm{m}$ in size, having a well-defined wall and a central inclusion or characteristic granular content stained with Giemsa). The disease did not occur among fishes (Cyprinus carpio L., Ctenopharyngodon idella Cuv. and Val., Sarotherodon mosambicus Peters, Hoplias malabaricus Bloch) kept together with the affected pacus. About $30-40 \%$ of the pacu stock succumbed. Since branchial lesions and heavy mortality were observed in this pacu population, the aetiological role of the epitheliocystis agent could be suspected. Based upon ultrastructural examinations this agent is considered to be a chlamydia or a chlamydia-like organism.
\end{abstract}

Key words: Epitheliocystis, pacu (Piaractus mesopotamicus), Brazil

Plehn (1920) was the first to describe a gill lesion that involved the presence of structures measuring 20-40 $\mu \mathrm{m}$ in the gill tissue of common carp (Cyprinus carpio L.). The disease was described as mucophilosis and the causative agent was reported to be Mucophilus cyprini, an unicellular alga. Since then the disease has been diagnosed in many countries of Europe as reviewed by Molnár and Boros (1981).

A similar condition was reported by Hoffman et al. (1969) in Lepomis macrochirus Rafinesque in the United States, and designated as epitheliocystis disease. The pathogen was classified into the Bedsonia group. Epitheliocystis disease has been described in many countries of the world in different fish species (Turnbull, 1993). Since 1990, it has been diagnosed in Australia (Anderson and Prior, 1992; Frances et al., 1997) and in South America (Venizelos and Benneti, 1996).

Based upon the electron microscopic features of the pathogen, Molnár and Boros (1981) pointed out that mucophilosis and epitheliocystis were the same

*Fax: (36-1) 342-7104 
disease. Although the name mucophilosis has a priority, epitheliocystis has been used and become widespread in the international literature.

Recently, most researchers (Paperna, 1977; Paperna et al., 1981; Paperna and Alves de Matos, 1984; Bradley et al., 1988; Fryer and Lannan, 1994; Groff et al., 1996; Frances et al., 1997) agree that the causative agent of the disease is a chlamydia-like organism.

Intensive efforts have been made in many countries (including Brazil) to establish pond fish farms with wild fishes living in the environment. One promising representative of such species is the pacu, Piaractus mesopotamicus Holmberg, 1893. In a pond farm stock of this cultured fish gill lesions resembling epitheliocystis and massive mortality due to this infection were found. As no data are available on whether or not this disease has been described in Brazil, pathological, direct microscopic, histopathological and electron microscopic examinations were performed in order to clarify the nature of the infection.

\section{Materials and methods}

Twelve severely affected moribund pacus were examined to study the lesions of the disease. The fish were bled by cutting the base of tail. Gross pathological examination was performed, then gill and skin scrapings were made for direct microscopy. Pieces from gill, skin, liver, kidney and intestine were cut from three fish for routine light microscopic examination. The samples were fixed in $10 \%$ buffered formalin solution, then embedded in paraffin wax and cut into $6 \mu \mathrm{m}$ thick sections for staining with haematoxylin-eosin, according to Giemsa, Ziehl-Neelsen, Brown-Brenn and by the periodic acid-Schiff's (PAS) procedure. As glutaraldehyde was not available on the spot, organ pieces for ultrastructural examination were also fixed in the same formalin solution. Samples embedded in synthetic resin (Durcupan) were examined in a transmission electron microscope (JEOL 100-S).

\section{Results}

\section{Epizootics}

The disease causing losses in a pacu stock was detected in a pond farm, in one fish pond only, at $23-24{ }^{\circ} \mathrm{C}$ water temperature. Besides pacus, Cyprinus carpio L., Ctenopharyngodon idella Cuv. et Val., Sarotherodon mosambicus Peters, and Hoplias malabaricus Bloch were also kept in the same pond but these fishes remained healthy without any signs of disease.

The 40-45 $\mathrm{cm}$ long pacus weighing 600-650 $\mathrm{g}$ did not show lesions on their body surface. The gills were more reddish than usual and covered with 
abundant mucus. Greyish-white, pinpoint- or pinhead-sized focal areas connected strongly to their base, demarcated from or turned gradually into their surroundings were detected randomly on the primary gill lamellae (Fig. 1). Signs of massive tissue necrosis were not found.

The disease caused approx. $30-40 \%$ mortality in the pacu population.

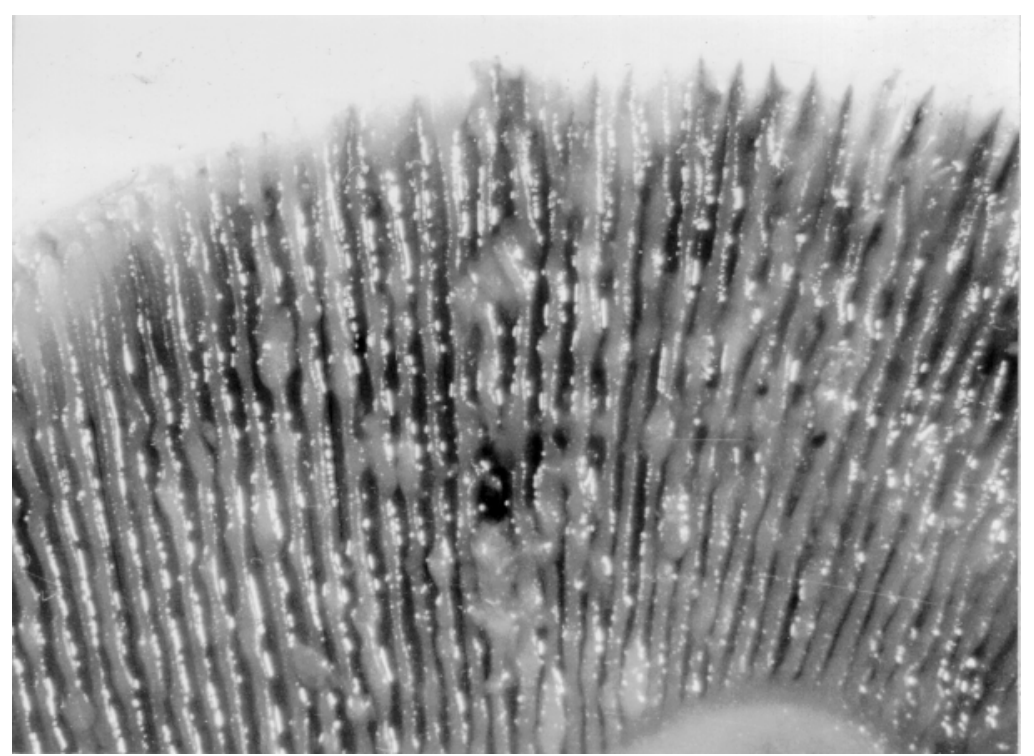

Fig. 1. Gross pathological lesions due to epitheliocystis disease on the primary gill lamellae. Unstained preparation $(\times 10)$

\section{Direct microscopic examination}

Besides the usual cellular elements, cell debris, oval or roundish structures (hypertrophic cells) with homogenous contents and a well-defined wall 10$20 \mu \mathrm{m}$ in diameter, as well as gill parasites Trichodina sp. and Gyrodactylus sp. were found in scrapings taken from the gill. Only Trichodina sp. and Gyrodactylus sp. but no hypertrophic cells were seen in scrapings taken from the skin.

\section{Histopathology}

In the sections stained with haematoxylin and eosin the usual structure of the gill proved intact in some places, but the respiratory epithelial cells were detached from the secondary respiratory lamellae, or proliferating epithelial cells strongly deformed the normal structure of the gill (Fig. 2).

Two types of hypertrophic cells occurred in the gill tissue (Fig. 3). 


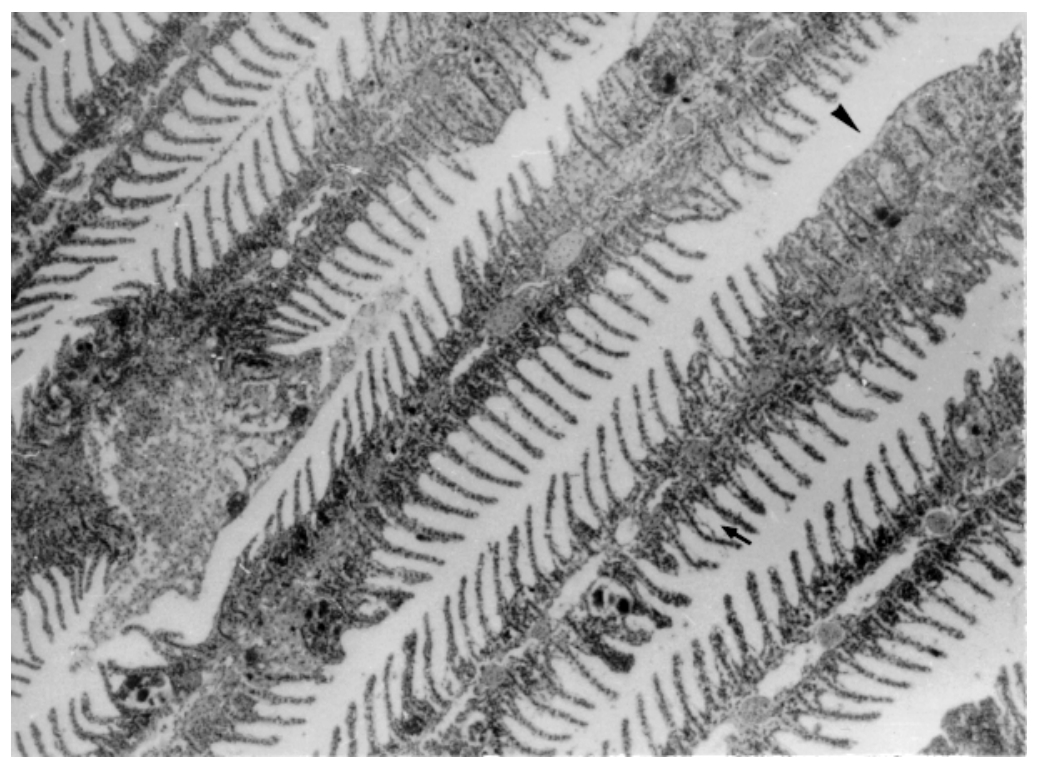

Fig. 2. Overall view of the gill. Intact areas and tissue proliferation (arrow head) alternate randomly. Detachment of respiratory epithelium (arrow). H.-E., $\times 50$

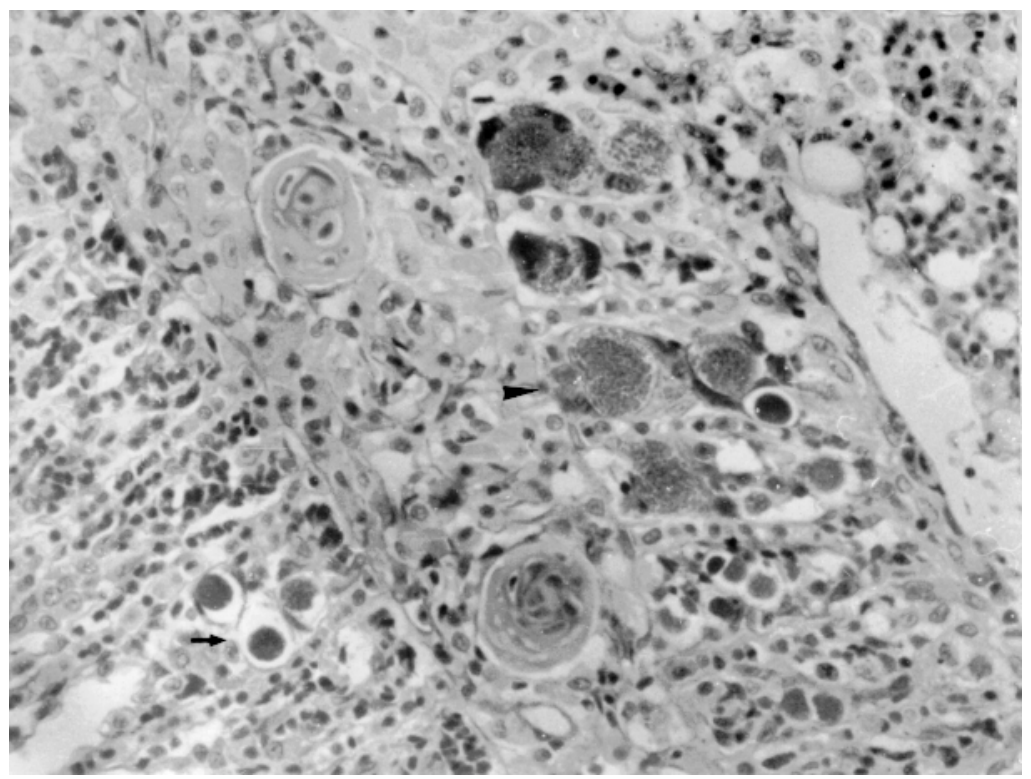

Fig. 3. Young (arrow) and matured (arrow head) hypertrophic cells in the gill filaments infected by the epitheliocystis agent. H.-E., $\times 200$ 
Oval or roundish structures $10-20 \mu \mathrm{m}$ in size were found among the proliferating epithelial cells between the secondary respiratory lamellae. These had a well-defined wall and a central inclusion consisting of homogeneously staining basophilic material, surrounded by a pale ring-like zone pushing the nucleus of the cell aside. No lesions and inflammatory cells were found in their surroundings; however, occasionally epithelial proliferation, hyperaemia or oedema could be seen in the respiratory lamellae. The central inclusion could be stained with Giemsa but not by the Ziehl-Neelsen, Brown-Brenn and PAS methods.

Other types of hypertrophic cells were usually found in nesting arrangement in the proliferating epithelium between the secondary respiratory lamellae or in the connective tissue of the primary gill lamellae. These cells, reaching a diameter of 30-40 $\mu \mathrm{m}$, had a well-defined wall and characteristic granular content, and their nuclei were pushed aside. The granular content stained with Giemsa but not by the Ziehl-Neelsen, Brown-Brenn and PAS methods. There were no reactions around the hypertrophic cells, however, epithelial and connective tissue proliferation was occasionally seen in the secondary gill lamellae, with hyperaemia and inflammatory cells (Fig. 4).

No lesions of epitheliocystis were noted in skin, liver, kidney and intestine sections prepared from the affected fish.

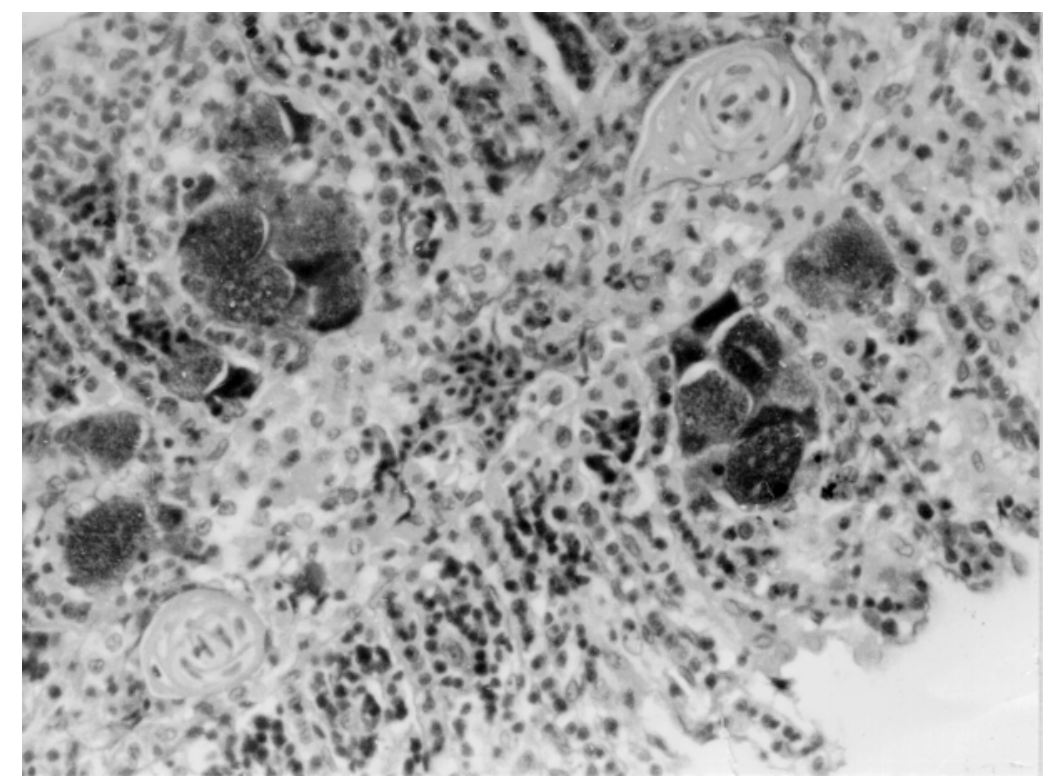

Fig. 4. Mature hypertrophic cells without any reaction around them, or surrounded by areas showing tissue proliferation, inflammation and haemorrhage. H.-E., $\times 200$ 


\section{Transmission electron microscopy}

Electron microscopic images showed the presence of the agent (chlamydia or chlamydia-like forms) but details were obscure due to inadequate fixation.

In the early stages of the infection the developing forms of the epitheliocystis agent occurred freely in the cytoplasm of affected cells. These were oval or roundish in shape, $280-400 \mathrm{~nm}$ in size, and were surrounded by a limiting membrane. The units had a less dense central area surrounded by a very dense peripheral area. The central and the peripheral area were separated by a limiting membrane.

Later on the developing forms of the epitheliocystis agent were located in an inclusion surrounded by a limiting membrane in the host cell. The inclusion was separated from the cell membrane by a narrow zone of cytoplasm containing remnants of cellular organelles. The major stages of the chlamydial developmental cycle (initial bodies $500-700 \mathrm{~nm}$, intermediate bodies $400-600 \mathrm{~nm}$ and dividing forms $800-1200 \mathrm{~nm}$ in size) were present within the inclusion (Fig. 5.)

In the last developmental stages the limiting membrane of the inclusion disappeared. The units of agent became embedded in a reticular matrix of low electron density within the cavity of the earlier inclusion. The units were separated by a trilaminar membrane.

\section{Discussion}

On the basis of the gross lesions and microscopic as well as transmission electron microscopic findings described above, the diagnosis of epitheliocystis disease was established. The present study is the first report of epitheliocystis in a cultured pacu stock. Since branchial lesions and heavy mortality were observed in a pacu population, and there were no pathological changes on the body surface and in the organs, the aetiological role of the epitheliocystis agent could be established.

The hypertrophic cells and the lesions found in their surroundings correspond to those described by Hoffman et al. (1969), Zachary and Paperna (1977) and Molnár and Boros (1981).

Anderson et al. (1965), Molnár and Boros (1981) and Turnbull (1993) support the conclusion that the causative agent of mucophilosis and epitheliocystis disease is closely related to the Chlamydia and Rickettsia groups. Our ultrastructural examinations indicate that this agent detected in pacu may be a chlamydia or a chlamydia-like organism. 


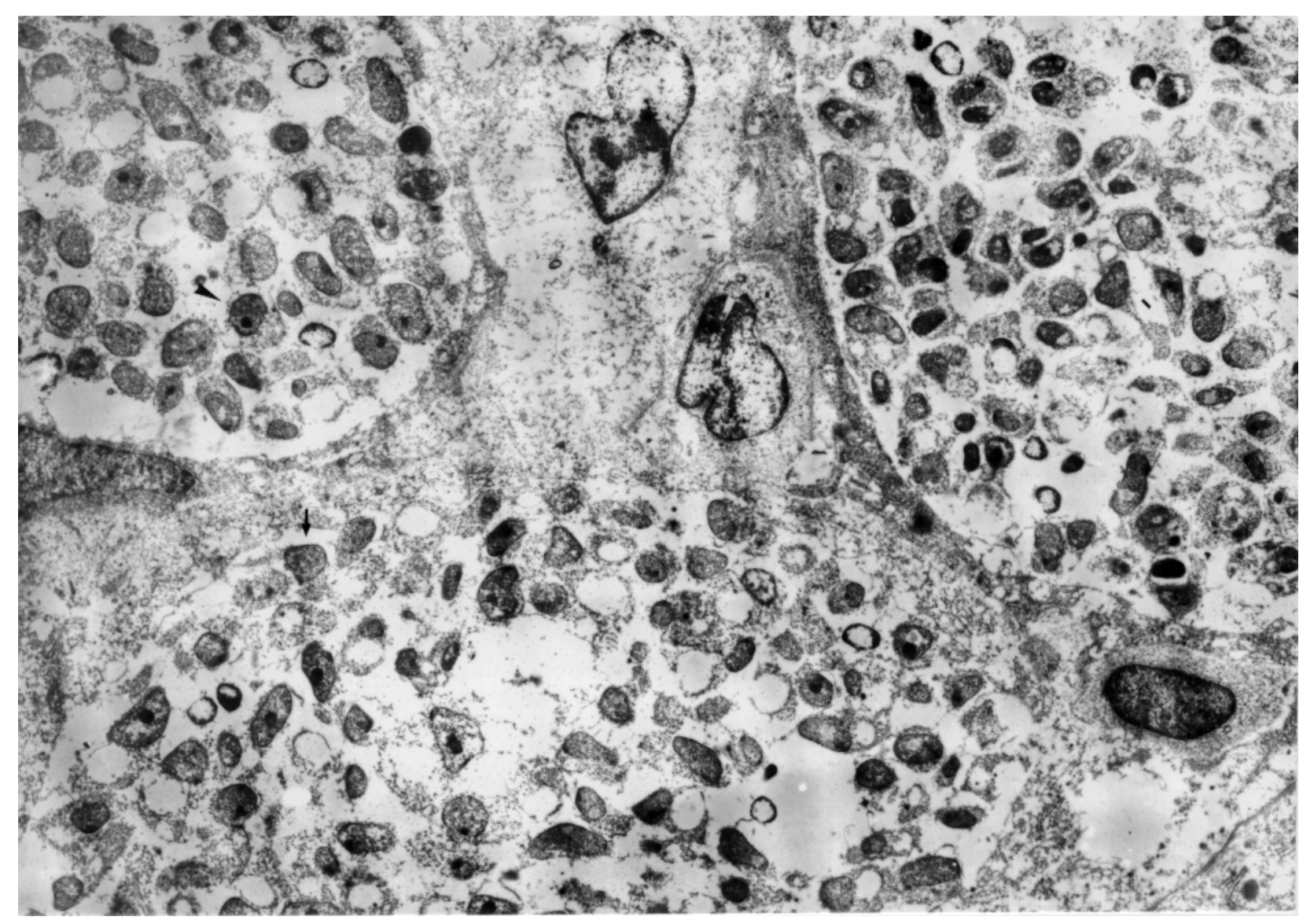

Fig. 5. Mature hypertrophic cells with characteristic wall and developmental forms (initial body [arrow], intermediate body [arrow head], dividing form [bar]). Transmission electron micrograph, $\times 4800$ 


\section{References}

Anderson, D. R., Hoops, H. E., Barile, M. F. and Berhneim, B. C. (1965): Comparison of the ultrastructure of several rickettsiae, ornithosis virus and mycoplasma in tissue culture. J. Bacteriol. 90, 1387-1403.

Anderson, I. G. and Prior, H. C. (1992): Subclinical epitheliocystis in barramundi, Lates calcifer, reared in sea cages. Aust. Vet. J. 69, 226-227.

Bradley, T. M., Newcomer, C. E. and Maxwell, K. O. (1988): Epitheliocystis associated with massive mortalities of cultured lake trout Salvelinus namaycush. Dis. aquat. Org. 4, 9-17.

Frances, J., Tennent, R. and Nowak, B. F. (1997): Epitheliocystis in silver perch. J. Fish Dis. 20, $453-457$.

Fryer, J. L. and Lannan, C. N. (1994): Rickettsial and chlamydial infections of freshwater and marine fishes, bivalves and crustaceans. Zool. Studies 33, 95-107.

Groff, J. M., LaPatra, S. E., Munn, R. J., Anderson, M. L. and Osburn, B. I. (1996): Epitheliocystis infection in cultured white sturgeon (Acipenser transmontanus): antigenic and ultrastructural similarities of the causative agent to the chlamydiae. J. Vet. Diagn. Inv. 8, 172-180.

Hoffman, G. L., Wolf, K. and Zwillenberg, L. O. (1969): Epitheliocystis, a new infectious disease of the blue gill (Lepomis macrochirus). Antonie van Leeuwenhoek J. Microbiol. Serol. 35, $156-158$.

Molnár, K. and Boros, G. (1981): A light and electron microscopic study of the agent of carp mucophilosis. J. Fish Dis. 4, 325-334.

Paperna, I. (1977): Epitheliocystis infection in wild and cultured sea bream (Sparus auratus, Sparidae) and grey mullets (Liza ramada, Mugilidae). Aquaculture 10, 169-176.

Paperna, I. and Alves de Matos, A. P. (1984): The development cycle of epitheliocystis in carp, Cyprinus carpio L. J. Fish Dis. 7, 137-147.

Paperna, I., Sabnai, L. and Zachary, A. (1981): Ultrastructural studies in piscine epitheliocystis: evidence for a pleomorphic developmental cycle. J. Fish Dis. 4, 459-472.

Plehn, M. (1920): Neue Parasiten in Haut und Kiemen von Fischen: Ichthyochytrium und Mucophilus. Zbl. I. Orig. 85, 275-281.

Turnbull, J. F. (1993): Epitheliocystis and salmonid rickettsial septicaemia. In: Inglis, V., Roberts, R. J. and Bromage, N. R. (eds) Bacterial Diseases of Fish. Blackwell Scientific Publications, London, pp. 237-255.

Venizelos, A. and Benneti, D. D. (1996): Epitheliocystis disease in cultured yellowtail Seriola mazatlana in Ecuador. J. World Aquacult. Soc. 27, 223-227.

Zachary, A. and Paperna, I. (1977): Epitheliocystis disease in the striped bass Morone saxatilis from the Chesapeake Bay. Can. J. Microbiol. 23, 1404-1414. 
